\title{
New Media as Power for Eradicating Communication Inequalities in Indonesia
}

\author{
Subekti W. Priyadharma, M.A. ${ }^{*}$ \\ ${ }^{1}$ Communication Management Program Study of Communication Science, Universitas Padjajaran, Bandung, Indonesia
}

\begin{abstract}
Bad news is good news," they say. This is the mantra of journalistic practice, which still trapped in the logic of market-oriented media institution. Until today, Indonesian media system is still driven by capitalistic and political motives of many actors especially media owners and political figures. Their domination in Indonesian media environment results in the colonization of media networks by political networks and vice versa. Controversial statements from and conflicts among political elites are "good" food for the media, which would attract audiences to buy their newspapers, watch their television and click on their sensational headlines that functions as a bait. Mass media public spheres are filled with this type of communication. Good News from Indonesia (GNFI) comes onto the surface of Indonesian media landscape to counter the negativity that the current media system holds. This paper analyzes how GNFI delivers its messages and, as an alternative media, uses its various media platform, most of them are online-based, to balance the inequality of communication about Indonesia.
\end{abstract}

Keywords: Communication Inequality; Alternative Media; Positivism; Counter-Public Sphere

\section{Introduction}

The Indonesian mass media, especially that of private national television broadcasters, is politically structured to a great extent. From 11 free-to-air national televisions, eight of them have a clear political footprint. Metro TV owner, Surya Paloh, is the Nasdem Party. MNCTV, RCTI, and Global TV, under the auspices of MNC Group, are owned by Hary Tanoesudibjo, the founder and Chairman of Perindo Party. Aburizal Bakrie, a former Minister of SBY [1] and former Chairman of Golkar Party, controls TV One and ANTV under Bakrie \& Brothers. Meanwhile, the owner of Trans TV and Trans7, Chairul Tanjung, once served as Coordinating Minister for Economics and Chief of National Committee for Economics under SBY's administration. Although the owners of SCTV and Indosiar are not involved directly in politics, those two broadcasters are owned by a single corporation, the EMTEK Group, which threatens the representation of diversity of public views[2,3]. Finally, one other national television, TVRI is a Public Broadcasting which is currently having a hard time to compete with private television companies due to minimal protection and inability to adapt to the free market system. The concentration of ownership of national private media in the hands of politicians presents a propensity to deliver bias messages that advocate the interest of media owners and their political connections. Research from Heychael and Dhona on Television Independence Ahead of the 2014 General Election confirmed these concerns. They mentioned that the media has become the "funnel of the owner's political interest"[4]. This bias news coverage is harmful for the public, for it tends to frame the owner or his political coalition with positive tones while reporting their political opponents with negativey[5,6].

Heychael and Wibowo, who examined 20 news programs in 10 Indonesian private national televisions, found, crime, corruption and accidents occupied the top three news topics that most frequently broadcasted and received most duration[7]. Inherently, criminality, corruption, and accident, all imply negative sound. Heychael and Wibowo added, there was an imbalance in the number and duration of news coverage for local and national news that favors Jabodetabek. Furthermore, from the small percentage of non-Jabodetabek coverage, news with negative tone continued to dominate. The top three positions (frequency/duration) for non-Jabodetabek news areas were filled with coverage on crime $(34.5 \% / 32.5 \%)$, accidents $(15.2 \% / 14.4 \%)$, and land conflicts $(5,6 \% / 5.4 \%)$. This data shows, even if there

\footnotetext{
* Corresponding author: subekti.w.priyadharma@unpad.ac.id
} 
was news coming from the periphery, it was mostly negative news[7].

The constellation of Indonesian mass media and the concentration of media ownership in the hands of politicians as described above not only threaten the diversity of ownership, but also the diversity of content. Many contents are being destroyed by political actor. For example, an issue about natural resources. A lot of political actors use natural disaster phenomena as an opportunity to gain popularity. The media, which is used as a political tool to seize power, makes the audience vulnerable to social friction caused by conflict-based political news between political actors. In addition, there is also a tendency that news coverage in the media with close political ties is susceptible to manipulation, which can lead to the manipulation of public opinion[8]. From the above background, this paper attempts to analyze the role of Good News from Indonesia (GNFI) as an alternative news source in countering those negative and biased messages.

\section{Methodology}

The case of GNFI is analyzed descriptively using two concepts in media theories: internal and external pluralism of media content and the counter-public sphere. The concept of diversity of media content in a media system recognizes the so-called 'plurality dualism'. Normatively, an ideal picture of mass media content would see a balanced representation of various views and opinions from various social groups in a society, about different range of public issues in every media. In so doing, no single group would dominate the public sphere of mass communication. Member of minority groups should also be given a fair chance to express their opinions and interests in the media so that they do not appear marginalized in the public sphere. This model of media practice is called internal pluralism. Brosius and Zubayr write, internal pluralism is the "variation of program offerings within a station ..."[9] (translated by author). However, nowadays no one can guarantee the existence of internal pluralism in private media, for each carries its own interest. As described above, such media practices may contain biased news reports.

In response to this development, internal pluralism needs to be supplemented by what is called external pluralism. According to this concept, if the media can not guarantee the diversity of content within their own media, then it will be achieved when there is a greater number of media institutions, which offer a wide range of opinions in their total (see the German 3. Rundfunkurteil or Broadcasting Decision)[10]. Thus, the concept of diversity is drawn to the macro level, i.e. the media system of a country. Nevertheless, journalistic ethics and principles remain the primary guidelines in order to avoid sloppy practice of journalism.

Counter-public sphere, or counter-publicity as some author prefers[11], was born as a response to mainstream or bourgeois public sphere that don't represent the dynamics of civil society at the grassroots level. Habermas himself neglected the distinctive plebeian public sphere in the first phase of his analysis of modern society only to acknowledge its existence later after which he revised his theory. Proletarian public sphere was never a derivative of bourgeois public sphere. It has its own culture that intrinsically characterized by its "counter project to the hierarchical world of domination"[12].

Due to the changing role of mass media, Downey and Fenton[11] spotted that the flow of communication in the mainstream public sphere increasingly becomes vertical, between the mass media (political actor, the state and media owner) in the center and the citizens in the periphery[13]. This is an unexpected deviance from the ideal type of public sphere in which horizontal communication between all parties involved was initially desired[14]. However, radical innovation in ICTs that has progressed since the end of the $20^{\text {th }}$ century makes ways for this ideal situation of public sphere to be reshaped and renewed in the form of "virtual counterpublic sphere". Now, the Internet rolls out its red carpet for netizens in the periphery to express their opinions and interests to a wider public while hoping for it to be considered important by the state, which then decides whether a public policy will be made in favor or against them. By seeing it that way, autonomous counter-public sphere can be "invented" by common citizens as an alternative to the dependent "invited" mass media public sphere[15].

\section{$3 \mathrm{D}$ iscussion}

This section looks at how GNFI counters negative contents of Indonesian mass media and thereby contributes to external pluralism of Indonesian media system. First of all, GNFI's positivism is already visible from the name it chooses. They boldly declare themselves to be the messengers of good news from Indonesia. "Good news" clearly has positive connotation, while "from Indonesia" indicates nationalism and the intention for promotion. This spirit of positivism is also identified on their website, in which GNFI "is committed to continue to spread positive and inspiring content from Indonesia to all GNFI Friends" (translated by author). Another positive connotation is again used by GNFI when they address the source/author of their articles. Here, they use the term "orang baik" (good people).

GNFI wants to counter negative and bias reporting of mainstream media as they intend "to be the main source of all independent and reliable Good News from Indonesia ... without any political, religious, or personal interests that might destabilize our vision." (translated by author) Their commitment to publish online (website, social media and e-Magazine) and also to produce nondigital products such as T-Shirt and tote bag in order to strengthen their brand, makes GNFI an alternative media that contributes to the creation of alternative public sphere or even of counter-public sphere as they resist the conflict-laden media practices, which adhere "bad news is good news" jargon. GNFI practically rebuts that claim by telling people that, "News is Good News". It seems that "Good" has become the new norm in the practice of 
alternative media of GNFI by branding all of its products with "Good" prefix, such as Good Store for its online store or "G-Magz" for its digital magazine. These good messages are what GNFI is trying to push into the Indonesian public sphere. The media practice of GNFI against the contemporary media norms suggests that public sphere is not static, as Habermas[14] initially believed, it is rather dynamic and always contested by multiple actors in order to shape public opinion according to their interests[11].

The logo of GNFI, representing the letter "G", which stands for "Good" and fulfilled with images that represent the richness of Indonesian cultures, with Garuda (national emblem of Indonesia) head at the top. Positivism is also evident from GNFI's tagline in its social media accounts: "Restoring Optimism, Rebuilding Confidence". This implies, they strive for positive media impact (optimism and confidence) on their audience, countering the negative media effects as many people complain about that normally to be seen in televisions which driven by rating and share system.

\section{Conclusion}

When the media is colonized by political and economic powers, we will receive biased media content in favor of those political and economic interests. This is the face of Indonesian mass media that is dominated by media moguls who become active players in Indonesian politics. In addition, the press that still prefers sensationalism over quality for the sake of rating number and circulation are causing unequal communication practices in terms of how the communication be processed and what the outcomes for a wider public might be. It takes a certain form of media entity with a spirit of positivism to eradicate this communication inequalities. Good News from Indonesia (GNFI) comes into the surface to address this problem, by restoring a fair share of positivism.

This paper is based on the fact that there is internal (within the media themselves) as well as external (within the media system in a country) inequality of media content, caused by the structure of media ownership. This structure permits acquisitive conglomeration and cross-ownership of media companies at the national and local levels. Consequently, mass communication public sphere that resulted from such media structure isn't freely accessible for all civil society groups. This condition tends to produce misrepresented public opinions. The presence of GNFI via alternative media channels with its alternative contents can be seen as an attempt to construct an autonomous counter-publics which is free from the intervention of those political and economic forces of the big media players.

However, this paper doesn't provide an explanation about the effects of positivism promoted by GNFI on the formation of (positive) public opinion and how it possibly affects decision-making process in the center as well as in the peripheries. In order to answer those questions, this paper recommends to follow-up this study with some researches on media effects.

\section{References}

1. Susilo Bambang Yudhoyono (SBY) was the 6th Indonesian president in two consecutive terms (2004-2009 and 2009-2014).

2. Y. Nugroho, D. A. Putri, S. Laksmi, Mapping the Landscape of the Media Industry in Contemporary Indonesia, Report Series, Engaging Media, Empowering Society: Assessing Media Policy and Governance in Indonesia through the Lens of Citizens' Rights, Research Collaboration of Centre for Innovation Policy and Governance and HIVOS Regional Office Southeast Asia, funded by Ford Foundation, Jakarta, CIPG and HIVOS (2012).

3. M. Lim, The League of Thirteen, Retrieved from http://www.merlyna.org on 27 October 2017 (2012).

4. M. Heychael and H. R. Dhona, Independensi Televisi Menjelang Pemilu 2014, Ketika Media Jadi Corong Kepentingan Politik Pemilik, Bag 1, Remotivi (2014).

5. M. Heychael, Independensi Televisi Menjelang Pemilu 2014, Ketika Media Jadi Corong Kepentingan Politik Pemilik, Bag 2, Remotivi (2014).

6. M. Heychael, Independensi Televisi Menjelang Pemilu 2014, Ketika Media Jadi Corong Kepentingan Politik Pemilik, Bag 3, Remotivi, (2014).

7. M. Heychael and K. A. Wibowo, Melipat Indonesia dalam Berita Televisi, Kritik Atas Sentralisasi Penyiaran, Remotivi (2014).

8. M. Heychael and R. Thaniago, Ketika Televisi Peduli. Potret Dilematis Filantropi Media, Remotivi (2013).

9. H. B. Brosius and C. Zubayr, Vielfalt im deutschen Fernsehprogramm, Eine Analyse der Angebotsstruktur öffentlich-rechtlicher und privater Sender, Ludwigshafen: Landeszentrale für private Rundfunkveranstalter, Band 12 (1996).

10. The German 3, Rundfunkurteil, Retrieved online from BVerfGE 57, 295 - 3. Rundfunkentscheidung, Retrieved from http://www.servat.unibe.ch/dfr/bv057295.html on 11 October, 2017.

11. J. Downey and N. Fenton, New Media, Counter Publicity and the Public Sphere, New Media \& Society, SAGE Publications, London, Thousand Oaks, CA and New Delhi, Vol. 5(2), pp. 185-202 (2003).

12. J. Habermas, Further Reflections on the Public Sphere, Habermas and the Public Sphere, ed. C. Calhoun, The MIT Press, Cambridge Massachusetts, pp.421-61 (1992).

13. J. Habermas, Between Facts and Norms: Contributions to a Discourse Theory of Law and Democracy, The MIT Press, Cambridge Massachusetts, German edition, 1992, English Translation (William Rehg) (1996).

14. J. Habermas, The Structural Transformation of the Public Sphere: An Inquiry into a Category of Bourgeois Society, Cambridge Massachusetts: The 
MIT Press, German edition, 1962, English Translation (Thomas Burger) (1991).

15. N. Kersting, Online Beteiligung - Elektronische Partizipation - Qualitätskriterien aus Sicht der
Politik, Internet und Partizipation: Bottom-up oder Top-down? Politische Beteiligungsmöglichkeiten im Internet, ed. Kathrin Voss (Wiesbaden: Springer Fachmedien, 2014), pp. 53-87 (2014). 